\title{
Pembelajaran Kitab Kuning dengan Bahasa Inggris di Pondok Pesantren Annuqayah Latee Guluk-Guluk Sumenep
}

\author{
Akh. Rosyidi ${ }^{1}$, Thorik Aziz ${ }^{2}$ \\ Institut Agama Islam Negeri Madura \\ 1akhrosyidipmk@gamil.com \\ 2thorikaziz@iainmadura.ac.id
}

\begin{abstract}
Keywords

Learning

Classical

Book1;

It was very rare the researchers who studied the learning of

Book1; classical book with English in Islamic boarding schools, whereas learning classical book with English was really important for the progress of the times, santri who were studying classical book with English could simultaneously get two fields of science and could be a special attraction in preaching to face modern society. The scope of this reseach was the implementation, understanding and the problems of the learning of classical book with English. This study was designed using a Case Study approach to find patterns associated with phenomena and identified relationships that influence phenomena. The type of study was an intrinsic case study that was undertaken because of disposed to understand cases in all. The results showed that, 1 . The implementation of the learning classical book with English was carried out twice a week that was called as the first session and the second session, while the method used was Bandongan and discussion method. Bandongan was held in the first session and the discussion method was carried out in the second session. 2. The level of santri's understanding of learning classical book with English was very good. 3. The problems were the implementation of the first session was very early morning, santri's understandings were different and some boards didn't join the first session of program. Learning classical book using English was worth maintaining and continues to be developed. The positive influence was felt a lot by santri, besides being able to learn English that they could also learn classical book both nahwu-sharraf science and its contents.
\end{abstract}

\begin{tabular}{ll} 
& Abstrak: \\
\hline Kata Kunci: & Sangat jarang sekali peneliti yang mengkaji tentang pembelajaran \\
Pembelajaran Kitab & Kitab Kuning dengan Bahasa Inggris di Pondok Pesantren, kegiatan \\
Kuning; & tersebut berperan penting terhadap kemajuan zaman, dengan \\
Bahasa Inggris; &
\end{tabular}


mengimplementasikan pembelajaran Kitab Kuning dengan Bahasa Inggris santri akan mendapatkan dua bidang ilmu dan menjadi daya tarik tersendiri dalam berdakwah menghadapi masyarakat modern. Ruang lingkup penelitian meliputi pelaksanaan, pemahaman, dan kendala dalam pembelaran kitab kuning dengan Bahasa Inggris. Penelitian ini didesain menggunakan pendekatan studi kasus dalam upaya menemukan gambaran pola yang terkait dengan fenomena dan mengindentifikasi hal-hal yang mempengaruhi. Sedangkan jenis kajiannya merupakan studi kasus intrinsik ditempuh karena keinginan peneliti untuk memahami kasus secara mendalam. Hasil penelitian menunjukkan bahwa 1 . Pelaksanaan pembelajaran Kitab Kuning dengan Bahasa Inggris terlaksana dua kali dalam satu minggu disebut dengan sesi pertama dan sesi kedua dengan menggunakan metode bandongan dan diskusi, metode bandongan dilaksanakan pada sesi pertama dan metode diskusi dilaksanakan pada sesi kedua. 2. Pemahaman santri terhadap pembelajaran Kitab Kuning dengan Bahasa Inggris sangat baik. 3. Kendala yang dihadapi yaitu pelaksanaan sesi pertama terlalu pagi, pemahaman anggota berbeda-beda dan beberapa pengurus tidak mengikuti kegiatan sesi pertama. Berdasarkan uraian di atas, pembelajaran Kitab Kuning dengan Bahasa Inggris layak dipertahankan dan terus dikembangkan. Pengaruh positif banyak dirasakan oleh santri, selain belajar Bahasa Inggris santri juga dapat belajar Kitab Kuning baik ilmu nahwusharraf maupun kandungannya.

\begin{tabular}{cc}
\hline \hline \multicolumn{2}{c}{ Received : 02 April 2020; Revised: 14 Mei 2020; Accepted: 26 Juni 2020 } \\
$\begin{array}{c}\text { (C) Tadris Jurnal Pendidikan Islam } \\
\text { Institut Agama Islam Negeri Madura, Indonesia }\end{array}$ \\
\hline \hline
\end{tabular}

\section{Pendahuluan}

Pondok Pesantren merupakan lembaga pendidikan Islam Indonesia yang sangat berpengaruh terhadap tersebarnya agama Islam di Nusantara. Pondok Pesantren sangat memainkan peranan penting dalam terbentuknya masyarakat yang berakhlaqul karimah. Pondok Pesantren juga dikenal kental dengan sistem pendidikan tradisional yang di dalamnya tidak lepas dari kajian-kajian kitab kuning sebagai bahan ajar utama. Kitab kuning pada saat ini tidak hanya diajarkan kepada santri menggunakan Bahasa Indonesia atau bahasa daerah masing-masing namun juga mengalami perkembangan dengan menggunakan bahasa asing. Kata Pesantren sendiri berasal dari kata santri yang mendapat imbuhan pe-an yang kemudian terbaca dengan Pesantren, yaitu sebutan untuk asrama atau tempat tinggal bagi para santri. Tujuan didirikannya Pondok Pesantren sebagai tempat proses belajar mengajar agama Islam, menjaga dan menyebarkannya. ${ }^{1}$

Pondok Pesantren pertama kali muncul pada abad ke $16 \mathrm{M}$, yang berada di Ampel di bawah asuhan (Raden Rahmat) Sunan Ampel, pada saat itu beliau mendidik dan mengkader para santri untuk menyebarkan agama Islam ke seluruh pelosok negeri bahkan terdapat beberapa santri yang ditugaskan ke

\footnotetext{
${ }^{1}$ Muhammad Priyatna, "Manajemen Pembelajaran Program Kulliyatul Mu'allimin al-Islamiyah di Pondok Pesantren al-Ihsan Baledah Bandung", Jurnal Edukasi Islami Pendidikan Islam, Vol. 6, (2017), 20.
} 
negara-negara tetangga. Santri-santri Sunan Ampel ini melahirkan banyak Pondok Pesantren di seluruh penjuru negeri, puncak kepesatan pesantren pada abad ke- 19 M sampai abad ke- $20 \mathrm{M}$, yaitu pada masa Syaikhona Kholil Bangkalan sekaligus bermunculan Kiai-Kiai besar Nusantara yang berpengaruh kemudian meneteskan Kiai-Kiai besar lainnya dan hampir di setiap kecamatan bahkan di desa berdiri sebuah Pondok Pesantren. ${ }^{2}$

Pondok Pesantren sebagai lembaga pendidikan tradisional mempunyai watak yang berciri khas, dikatakan demikian karena Pondok Pesantren mempunyai tradisi keilmuan yang berbeda dengan tradisi keilmuan lembagalembaga lainnya. Salah satu ciri khas pembeda pendidikan Pondok Pesantren merupakan Kitab Kuning, yang ditulis dengan menggunakan bahasa Arab baik oleh cendikiawan muslim Arab maupun Indonesia. ${ }^{3}$

Pendidikan Pondok Pesantren pada awalnya menerapkan pola pembelajaran terbuka yakni seorang kiai membaca, menerjemahkan dan menerangkan kitab yang sedang diajarkan. Kitab yang dipakai merupakan pengklasifikasian kelas yang diterapkan untuk pendidikan santri. ${ }^{4}$ Sistem pendidikan Pondok Pesantren seperti di atas mudah ditemui di berbagai Pondok Pesantren di Indonesia terutama di daerah Jawa yang masih menganut sistem pendidikan tradisional.

Ciri-ciri Pondok Pesantren tradisional salah satunya dapat dilihat dari sistem pembelajarannya, seperti sistem pembelajaran bandongan dan sorogan, begitu pula dengan materi yang diajarkanpun menggunakan kitab-Kitab Kuning, kitab berbahasa Arab karya dari berbagai ulama baik dari Indonesia sendiri maupun luar negeri. ${ }^{5}$

Seiring perkembangannya, Pondok Pesantren mulai maju dan dapat bersaing mengikuti perkembangan zaman. Bahkan Pondok Pesantren sekarang ini tidak hanya fokus pada aspek ilmu agama saja bahkan mulai merambah ilmu umum. Sebagai salah satu bukti terdapat beberapa lembaga pendidikan formal di Pondok Pesantren yang tidak hanya mengajarkan ilmu agama namun juga ilmu umum. Bentuk upaya berikutnya pesantren tidak hanya fokus pada pendidikan tradisional semata yaitu dengan didirikannya lembaga-lembaga formal yang disebut dengan madrasah atau sekolah. Pengambilan keputusan tersebut dengan alasan yang sangat relevan yaitu untuk membekali santri berbagai ilmu pengetahuan dan keterampilan dalam rangka mengikuti perkembangan tuntutan zaman yang semakin maju dan menjadi bekal kelak ketika pulang dan berinteraksi langsung dengan masyarakat.

Berbagai inovasi dilakukan untuk mengembangkan Pondok Pesantren, baik oleh masyarakat maupun oleh pemerintah. Masuknya pengetahuan umum dan keterampilan merupakan upaya untuk memberikan bekal tambahan yaitu selain bekal ilmu agama santri juga dibekali dengan ilmu dan keterampilan yang lain agar ketika pulang ke kampung halaman santri lebih mudah dalam hidup bermasyarakat. Terdapat beberapa Pondok Pesantren yang fokus dan cenderung membina dan mengembangkan madrasah atau sekolah baik dari tingkat dasar sampai tingkat menengah maupun perguruan tinggi. ${ }^{6}$

\footnotetext{
${ }^{2}$ Budiono Hadi Sutrisno, Sejarah Wali Songo Misi Pengislaman di Tanah Jawa, (Jogjakarta Graha Pustaka, 2009), 16.

${ }^{3}$ Abdurrahman Wahid, Menggerakkan Trasidi: Esai-Esai Pesantren. (Jogjakarta: LkiS,2001), 157.

${ }^{4}$ Muhammad Jamaluddin, "Metamorfosis Pesantren di Era Globalisasai", Jurnal KARSA, Vol 20 no 1, (2012), 128.

${ }^{5}$ Ahmad Muhakamurrohman, "Pesantren, Santri, Kiai dan Tradisi", Jurnal Kebudayaan Islam, Vol. 12, No. 2 (Juli-Desember 2014), 113.

${ }^{6}$ Adi Fadli, "Pesantren: Sejarah dan Perkembangannya", EL- HIKAM: Jurnal Pendidikan dan Kajian Kelslaman, Vol. V Nomor 1, (Januari-juni 2012), 39.
} 
Pondok Pesantren pada saat ini banyak mengembangkan keilmuan dan keterampilan yang menjurus pada bidang tertentu, seperti program tahfidh alQur'an dan pengembangan skill Bahasa Asing baik Bahasa Arab maupun Bahasa Inggris. Hal tersebut dilakukan dalam upaya menghadapi tantangan dan perkembangan zaman agar santri tidak gagap dan mampu bersaing dengan dunia modern. Tidak sedikit Pondok Pesantren yang merespon positif hal tersebut, beberapa contoh Pondok Pesantren yang mengembangankan skill bahasa yaitu Pondok Pesantren Darussalam Gontor Ponorogo, Pondok Pesantren al Amien Prenduan Sumenep dan beberapa Pondok Pesantren lainnya.

Pondok Pesantren Annuqayah Latee sendiri merupakan Pondok Pesantren yang sangat menjaga tradisi ilmu agama, santri yang mondok disana belum sah disebut santri dan/atau alumni kalau belum menguasai kitab kuning. Bahkan hal itu diinstruksikan langsung oleh pengasuh bahwa santri latee wajib menguasai ilmu agama atau kitab kuning selama berada di pesantren dan harus diprioritaskan dari pelajaran yang lain. Dalam upaya mewujudkan cita-cita tersebut Pondok Pesantren Annuqayah Latee memperbanyak kegiataan keagamaan baik yang bersifat formal maupun non formal bahan ppengasuh dan putra pengasuh turun langsung dalam mensukseskan cita-cita pesantren seperti menjadi tenaga pengajar utama dalam beberapa pembelajaran kitab kuning tidak hanya itu dalam dua tahun terakhir Pondok Pesantren Annuqayah Latee membuat lokal khusus untuk santri yang berkeinginan kuat belajar kitab kuninig secara fokus.

namun Pondok Pesantren Annuqayah Latee juga tidak menutup mata dengan perkembangan ilmu pengetahuan salah satu bentuk nyata yakni terdapat lembaga Pengembangan Bahasa Inggris di Pondok Pesantren Annuqayah Latee lembaga bahasa inggris disana mengajarkan Kitab Kuning dengan menggunakan Bahasa Inggris sebagai bahasa utama dalam memberikan makna serta memberikan penjelasan kandungan yang terdapat dalam Kitab tersebut. memadukan pembelajaran Kitab Kuning dengan menggunakan Bahasa Inggris. Tidak mudah bagi santri untuk memadukan pembelajaran Kitab Kuning dengan menggunakan Bahasa Inggris, karena santri tidak hanya dituntut paham pelajaran nahwu-sarraf akan tetapi santri juga perlu belajar dasar-dasar gramatikal Bahasa Inggris untuk digunakan dalam memberikan arti pada Kitab Kuning dan sebagaimana diketahui dan diakui oleh banyak pihak bahwa belajar membaca dan memahami Kitab Kuning bukan perkara mudah butuh keseriusan dan ketekunan agar dapat menguasai Kitab Kuning. Oleh karena itu, peneliti tertarik melakukan penelitian tentang pelaksanaan pembelajaran kitab kuning dengan Bahasa Inggris, kemampuan santri dalam memahami pembelajaran kitab kuning dan kendala-kendala yang terdapat dalam pembelajaran Kitab Kuning dengan Bahasa Inggris di Pondok Pesantren Annuqayah Latee Guluk-Guluk Sumenep.

\section{Metode Penelitian}

Penelitan ini didisain dengan pendekatan Studi Kasus dalam upaya menemukan gambaran pola yang terkait dengan fenomena dan mengidentifikasi hubungan-hubungan yang memengaruhi fenomena. Sedangkan jenis kajiannya menggunakan studi kasus intrinsik yang ditempuh karena keinginan peneliti untuk memahami kasus tertentu dalam seluruh kekhususan dan aspek kesederhanaannya, mengarah pada pilihan objek yang diteliti bukan pada 
pemilihan metodologisnya. ${ }^{7}$ Peneliti disini meupakan peneliti non partisipatif yakni hanya meneliti dan tidak ikut berperan dalam kegiatan yang sedang diteliti.

Jenis data yang dipilih merupakan data kualitatif yang dideskripsikan dalam paparan kalimat narasi. Khusus studi dokumentasi, peneliti melakukan telaah berdasarkan fakta-fakta yang ditemukan dalam bentuk dokumen-dokumen penting yang berhubungan dengan penelitian. Penentuan subjek dipililh berdasarkan informan yang dipandang mampu memberikan data sesuai tujuan penelitian.

Analisa data dilakukan pada saat pengumpulan data berlangsung dan setelah selesai pengumpulan data. Aktifitas dalam analisis data, menggunakan teknik reduksi data, display dan verifikasi. Langkahanalisa menggunakan model $L$. $R$. Gay, yaitu melakukan identifikasilah tema-tema dari data yang dikumpulkan secara induktif dari tema-tema yang besar menjadi tema kecil, kemudian dibuat kode untuk perencanaan, pelaksanaan, evaluasi, maupun hasilnya. Sedangkan interpratasi memggunakan interpetasi ruang dan waktu model Kridalaksana, yaitu konteks yang berupa aspek-aspek lingkungan fisik atau sosial yang kait mengait dengan ujaran tertentu, pengetahuan yang sama antara pembicara dan pendengar sehingga pendengar paham apa yang dimaksud pembicara. ${ }^{8}$

Selanjutnya dilakukan pemeriksaan keabsahan data dengan melakukan member checking, yaitu dengan melakukan pengecekan temuan dengan partisipan demi keakuratan temuan, yaitu dengan mengajukan pertanyaan pada satu atau lebih partisipan dalam memperoleh hasil yang akurat. ${ }^{9}$

\section{Pembahasan}

\section{A. Sejarah Pondok Pesantren Annuqayah}

Pondok Pesantren Annuqayah merupakan lembaga pendidikan berbasis keislaman yang didirikan oleh K.H. Muhammad Syarqawi pada tahun 1887 M. K.H. Muhammad Syarqawi merupakan seorang musafir dan ulama besar yang alim berasal dari Kudus Jawa Tengah. Disinyalir memiliki hubungan yang erat dengan silsilah Wali Songo, yaitu Sunan Kudus. Dalam pengembaraan pendidikan, K.H. Muhammad Syarqawi pernah menetap di Mekkah menuntut ilmu dan menurut beberapa sumber satu masa dengan K.H. Nawawi Al-Banteni Banten dan K.H. Mohammad Khalil Bangkalan. Setelah menyelesaikan masa pendidikan, kemudian pindah ke Desa Prenduan. Di daerah tersebut keturunan K.H. Muhammad Syarqawi mendirikan Pondok Pesantren Al-Amien dan perkembangan berikutnya K.H. Muhammad Syarqawi memutuskan untuk menetap di Desa Guluk-Guluk Sumenep dan mendirikan sebuah Pondok Pesantren yang kemudian diberi nama Pondok Pesantren Annuqayah. ${ }^{10}$ Pondok Pesantren Annuqayah merupakan sebuah Pondok Pesantren yang terbagi dalam beberapa daerah. Masing-masing daerah dipimpin oleh seorang pengasuh dan dibantu oleh keluarga dhalem yang lain. Setiap daerah memiliki hak otonom untuk mengelola Pondok Pesantren daerah sendiri tanpa menafikan aturan yang ada di Pondok Pesantren Annuqayah pusat.

\footnotetext{
${ }^{7}$ Robert E Stake, Study Kasus dalam Densin, Norman K. dan Linclon Younna, (Handbooks of Qualitative research). Terjemah oleh, Dariynato, Badrus Samsul Fata dan Jhon Rinadi, (Jogjakarta: Pustaka Pelajar), 301.

${ }^{8}$ Amir Hamzah, Metode Penelitian Kualitatif, Rekonstruksi Pemikiran Dasar, (Malang: Literasi Nusantara, 2009).

9 Jhon W. Creswell, Research, Pendekatan Kualitatif dan kuantitatif dan Mixed. Terjemah oleh, Ahmad Fawaid, (Jakarta: Pustaka Pelajar 2012).

${ }^{10}$ Tim Penyusun, Laporan Akhir Tahun Pondok Pesantren Annuqayah Latee, (Sumenep: Alatee Press, 2018), 1.
} 
Pondok pesantren daerah yang berada di bawah naungan Pondok Pesantren Annuqayah, yaitu daerah Latee (putra), Latee I, Latee II, \& Latee Utara (putri), Al-Idrisi (putri), An-Najah (putri), Lubangsa Raya (Putra-Putri), Lubangsa Tengah (putri), Lubangsa Selatan (putra-putri), Lubangsa Utara (PutraPutri), Kusuma Bangsa (putra-putri), Karang Jati (putra-putri), Al-Furqan (putraputri), dan Nurul Hikmah (putra-putri). Meskipun setiap Pondok Pesantren daerah memiliki hak otonom, tetapi dalam hal pendidikan formal tetap dalam satu naungan pesantren pusat. Jumlah santri yang mukim di Pondok Pesantren Annuqayah saat ini \pm 8.000 santri putra putri yang berasal dari berbagai kepulauan di Nusantara yang tersebar di Pondok Pesantren daerah tersebut. ${ }^{11}$ Data tersebut hanya meliputi santri-santri yang bermukim di Pondok Pesantren Annuqayah saja sedangkan santri kalong tidak tercatat dalam data statistik Pondok Pesantren Annuqayah.

Pondok Pesantren Annuqayah Sampai saat ini telah memiliki banyak lembaga pendidikan, baik formal maupun non formal. Lembaga pendidikan formal yang ada di lingkungan Pondok Pesantren Annuqayah antara lain: TK Anaprasa, Ml 1 Annuqayah, Ml 2 Annuqayah, Ml 3 Annuqayah, MTs. 1 Annuqayah (Putra-Putri), MTs. 2 Annuqayah putra, MTs. 3 Annuqayah Putri, MA 1 Annuqayah (Putra-Putri), MA 2 Annuqayah Putra, MA Tahfidh Annuqayah Putra, SMA Annuqayah Putra, SMA 3 Annuqayah Putri, SMK Annuqayah Putra, SMK Annuqayah Putri, dan dua kampus yaiut Institut Ilmu Keislaman Annuqayah (Instika) dan Institut Sians Teknologi Annuqyah (IST Annuqayah) Putra dan Putri. Sementara untuk pendidikan non-formal terdapat Madrasah Diniyah yang dikelola secara independen oleh masing-masing daerah. ${ }^{12}$ Pelaksanaan jam kegiatan belajar mengajar yang dilaksanakan bervariasi, tergantung kebijakan masing-masing daerah.

Pondok Pesantren Annuqayah juga didukung dengan beberapa lembaga pengembangan bakat dan keterampilan, antara lain yaitu: Markazul Lughah alArabiyah (Markaz), English Education Program (EEP), Lembaga Pengembangan Tilawatil Quran (LPTQ), Lajnah Falakiyah (LF), Pramuka (Gudep 0761), dan klub-klub lainnya. Lembaga-lembaga tersebut terdiri dari pengurus yang melibatkan santri dari berbagai daerah di Pondok Pesantren Annuqayah. ${ }^{13}$

Pondok Pesantren Annuqayah Latee sendiri merupakan salah satu daerah di bawah naungan Pondok Pesantren Annuqayah yang didirikan oleh K.H. Abdullah Sajjad pada tahun 1923. K.H. Abdullah Sajjad merupakan salah seorang putra K.H. Moh. Syarqawi yang paling gigih dalam perjuangan fisik melawan penjajah. Pada tahun 1947, K.H. Abdullah Sajjad gugur sebagai Syahid dalam mempertahankan Negara dari agresi militer Belanda. Setelah K.H. Abdullah Sajjad wafat, Pondok Pesantren Annuqyah Latee mengalami kefakuman kepemimpinan. Kefakuman tersebut ternyata dapat diatasi oleh Kiai Anwar, santri K.H. Abdullah Sajjad yang berasal dari Gadu Barat, Ganding Sumenep dan dibantu oleh K.H. Moh. Mahfudz Husaini. Pada tahun 1953 kepengasuhan dialihkan kepada K.H. Ahmad Basyir AS putra K.H. Abdullah Sajjad yang berlangsung hingga tahun 2017. ${ }^{14}$ Setelah itu, kepengasuhan dialihkan kepada K.H. Abd. A'la sebagai pengasuh dengan dibantu oleh K. M.

\footnotetext{
${ }^{11}$ lbid.,

${ }^{12}$ lbid., 2

${ }^{13}$ Ibid.,

${ }^{14}$ Tim Penyusun, Jejak Masyayikh Annuqayah, Kado Alumni Pondok Pesantren Annuqayah Latee, (Sumenep: Alatee Press), 22.
} 
Ainul Yaqin, K. Hazm, K.H. A. Hanif Hasan, dan K.H. Moh. Musthafa Erfan sebagai anggota Dewan Pengasuh.

Pondok Pesantren annuqayah Latee terletak kurang lebih 150 meter di sebelah timur Masjid Jamik Annuqayah. Sejak tahun 2015 sampai sekarang mengalami peningkatan jumlah santri yang cukup signifikan. Hal tersebut dibuktikan dengan jumlah santri yang mencapai angka 1000 lebih. Santri-santri tersebut, berasal dari daerah Sumenep, Pamekasan, Sampang, Bangkalan, Jember, Banyuwangi, Situbondo, Bondowoso, Pasuruan, Probolinggo, Lumajang, Surabaya, Sidoarjo, Bali, Kalimantan, Jawa Tengah, Jawa Barat, Jakarta, Lampung, dan Riau. ${ }^{10}$

Kegiatan pendidikan dan pengajaran pada awal-awal di Pondok Pesantren Annuqayah Latee masih sangat sederhana, yaitu dengan menerapkan metode konvensional tradisi pesantren, seperti pengajian al-Qur'an, pengajian Kitab Kuning dengan metode sorogan, dan wetonan/bandongan, dan semacamnya. Kegiatan pendidikan dan pengajaran ini dapat dikatakan sebagai embrio bagi sistem pendidikan dan pengajaran, hingga pada beberapa tahun berikutnya sistem pendidikan dan pengajaran ini semakin mapan dengan tetap mempertahankan tradisi keilmuan pesantren klasik dalam pola pengajarannya. Hal ini, pada tataran praktis dijalankan oleh Madrasah Diniyah Annuqayah Latee (Madal), Pengajian al-Qur'an dan Kitab (Depak), dan Madrasah SKIA ${ }^{16}$.

Pondok Pesantren Annuqayah Latee juga mengembangkan keterampilan bahasa dengan didirikan Lembaga Pengembangan Bahasa Arab yang bernama Darul Lughah wal Fiq as Salafi kemudian disingkat menjadi (DALFIS) dan Lembaga Pengembangan Bahasa Inggris yang bernama English Area of Latee yang disingkat menjadi (EAL). Kedua lembaga tersebut menjadi pusat belajar bagi santri yang ingin mengembangkan skill mereka dalam bidang kebahasaan.

Penelitian tentang pembelajaran Kitab Kuning dengan Bahasa Inggris fokus pada lembaga bahasa inggris yang berada di bawah naungan Pondok Pesantren Annuqayah Latee yaitu English Area of Latee (EAL) selanjutnya dibaca EAL. EAL merupakan nama sebuah lembaga Bahasa Inggris yang berada di bawah naungan Departemen Pengembangan Dua Bahasa (DPDB) Pondok Pesantren Annuqayah Latee, EAL berdiri pada tanggal 15 Agustus 2009 dan pada saat ini sudah mencapai satu dekade. Dalam usia yang sudah mencapai angka kepala satu tentunya lembaga ini mengalami banyak perubahan, perkembangan serta kemajuan mulai dari sistem pembelajaran sampai pada prestasi yang diraih. ${ }^{17}$

Sejarah terbentuk lembaga tersebut muncul dari semangat tinggi dari para santri untuk mempelajari Bahasa Inggris sebagai salah satu bentuk kemajuan santri Pondok Pesantren. Proses terbentuknya melalui rapat pengurus dari berbagai departemen kemudian diajukan kepada pengasuh untuk mendapatkan legitimasi. Pengasuh melegitimasi dan merestui lembaga Bahasa Inggris yang kemudian bernama Englilsh Area of Latee (EAL) namun Pengasuh memberikan syarat bahwa harus terdapat pengajian Kitab Kuning di lembaga tersebut. Tujuan Pengasuh agar ciri khas dan marwah Pondok Pesantren Annuqayah Latee tetap terjaga yaitu mencetak santri yang dapat membaca dan memahami Kitab Kuning. ${ }^{18}$ Oleh karena itu, salah satu kegiatan wajib yang

\footnotetext{
${ }^{15}$ Tim Penyusun, Laporan Akhir Tahun, 3.

${ }^{16}$ Ibid.,

${ }^{17}$ Tim Penyusun, Laporan Akhir Tahun English Area of Latee Pondok Pesantren Annuqayah Latee, 2018, 1

18 lbid., 3.
} 
terdapat di EAL yaitu kegiatan pengajian Kitab Kuning agar ciri khas Pondok Pesantren Annuqayah Latee sebagai daerah yang menjaga tradisi menguasai berbagai Kitab Kuning tetap terjaga dan berkembang.

Santri dapat mendaftar untuk masuk lembaga Bahasa Inggris melalui seleksi yang dilakukan oleh pengurus EAL setiap semester. Yaitu semester ganjil dan genap dengan ketentuan umum mininal kelas delapan MTs dan maksimal kelas sebelas SMA sederajat. Setelah dinyatakan lulus santri masih masuk karantina selama 1 bulan kemudian diseleksi kembali dan diambil 10 terbaik. EAL mempunyai 4 kelas yang harus dituntaskan oleh anggta selama belajar di sana yaitu Speaking Class, Listening Class, Reading Class dan Translation Calss dan masing-masing kelas tersebut ditempuh dalam jangka 1 semester. Jadi, anggota dapat menyelesaikan masa pendidikan di EAL paling cepat selama jangka waktu 2 tahun. ${ }^{19}$ Sedangkan yang menjadi pengurus EAL marupakan anggota senior yang telah menyelesaikan pendidikan di EAL namun hanya beberapa lulusan yang diangkat menjadi pengurus yaitu alumni yang dianggap mampu mengemban tugas dan dapat bertanggung jawab.

Beberapa prestasi yang diraih oleh anggota EAL, yaitu: juara 1 dan 2 lomba Pidato Bahasa Inggris di STAIN Pamekasan (sekarang IAIN Madura) tahun 2013, juara 1 lomba karya tulis ilmiah Bahasa Inggris di UNISMA Malang tahun 2014, juara umum dalam lomba Ajang Prestasi Keagamaan Madura yang diadakan oleh Pondok Pesantren Darul Ulum Banyuanyar Pamekasan tahun 2015, juara 1 debat Bahasa Inggris yang diselenggarakan di Pondok Pesantren al Amien Prenduan Sumenep tahun 2016 selanjutnya juara 2 lomba pidato Bahasa Inggris di UIN Sunan Ampel Surabaya tahun $2017 .{ }^{20}$ Data tersebut merupakan data lama yang tersimpan di file laporan akhir tahun EAL dan belum diperbaharui, jadi data yang tercantum hanya data prestasi anggota sampai tahun 2017.

\section{B. Pelaksanaan Pembelajaran Kitab Kuning dengan Bahasa Inggris di Pondok Pesantren Annuqayah Latee}

Pelaksanaan pembelajaran Kitab Kuning di lembaga Bahasa Inggris Pondok Pesantren Annuqayah Latee dilaksanakan dua kali dalam satu minggu, yaitu pada hari rabu pagi atau progam pembelajaran sesi pertama, sekitar jam 05.00 WIB sampai jam 06.00 WIB setelah sholat subuh berjamaah. Namun apabila pengajar berhalangan pada hari itu diganti dengan hari yang lain, hal ini akan mengeser pelaksanaan pembelajaran pada sesi kedua karena pembelajaran Kitab Kuning sesi akan terlaksana apabila telah menyelesaikan pembelajaran sesi pertama. ${ }^{21}$

Pembelajaran dimulai dengan membaca irriguler verb sambil menuggu pengajar yang bersangkutan tiba di kelas. Kegiatan tersebut diikuti oleh seluruh santri yang bermukim di EAL baik yang sudah menjadi pengurus atau masih berstatus anggota, kegiatan ini berlangsung sejak tiga tahun yang terakhir yaitu pada tahun pelajaran 2017-2018. Sesi pertama, para santri hanya memberikan makna, mendengarkan penjelasan yang sampaikan oleh pengajar, anggota juga mencatat hal-hal penting yang terkandung pada Kitab Kuning tersebut kebetulan Kitab yang digunakan adalah Kitab Tafsir Jalalain yaitu menjelaskan tentang tafsir dan kandungan-kandungan al-Qur'an.

\footnotetext{
${ }^{19}$ Wawancara dengan Direktur EAL M. Ramdan Efendi, 9 Oktober 2019.

${ }^{20}$ Berdasarkan data prestasi anggota English Area of Latee (EAL) yang disampaikan oleh Direktur M. Ramdan Efendi.

${ }^{21}$ Wawancara dengan direktur EAL M. Ramdan Efendi 9 Oktober 2019.
} 
Metode pembelajaran Kitab Kuning yang digunakan di EAL pada sesi pertama yakni Metode Bandongan. Metode tersebut digunakan pada proses pembelajaran sesi pertama, yaitu pada proses pemberian materi utama yang disampaikan oleh seorang pengajar, Metode Bandongan adalah metode dengan sistem sekelompok santri mendengarkan Ustad yang membaca, menerjemahkan dan menjelaskan tentang kandungan dari kitab tersebut. Setiap santri membuat catatan-catatan tentang penjelasan atau kata-kata yang sulit dipahami. Pemilihan metode bandongan agar santri mendengarkan dan mencatat penjelasanpenjelasan yang disampaikan oleh Ustad sebagai bahan ketika akan melaksanakan kegiatan pemebelajaran sesi kedua. ${ }^{22}$

Pelaksanaan pembelajaran sesi kedua dilaksanakan pada malam kamis, yaitu sekitar jam 20.30 WIB sampai batas waktu maksimal jam 22.00 WIB setelah pulang dari Madrasah Diniyah. Sesi kedua sangat berbeda dengan sesi pertama, karena para anggota yang menjelaskan kembali materi yang telah dipelajari pada sesi pertama. Namun, terdapat pengurus yang mengomando atau yang memimpin kegiatan ini. Sebelum masuk pada kegiatan pembelajaran, anggota telah terbagi menjadi empat kelompok secara acak dari masing-masing tingkatan kelas. ${ }^{23}$

Kegiatan pembelajaran dimulai dengan dipimpin oleh satu pengurus yang bertugas, biasanya setiap minggu pengurus dijadwal untuk memimpin proses pembelajaran. Selanjutnya satu persatu dari masing-masing kelompok maju ke depan untuk mempresentasikan hasil belajar yang telah diperoleh sebelumnya. Setelah kelompok tersebut selesai presesntasi, kelompok yang lain mulai masuk pada sesi diskusi dengan memberikan pertanyaan yang berkaitan dengan teks yang telah dipresentasikan baik dari segi kandugan kitab yang dijelaskan ataupun dari segi ilmu nahwu-sharraf.

Metode pembelajaran kedua yang digunakan yakni metode diskusi, metode ini dipilih agar anggota lebih aktif berbicara dan bertukar pikiran karena pada sesi ini anggota yang menjadi pemeran utama sedangkan pengurus hanya mengomando atau memimpin jalannya diskusi. Metode diskusi adalah metode pembelajaran yang menghadapkan peserta didik pada suatu permasalahan, tujuan utama metode ini untuk memecahkan suatu masalah, menjawab pertanyaan, menambah dan memahami pengetahuan peserta didik dan membuat suatu keputusan. ${ }^{24}$

Metode diskusi dilaksanakan pada sesi kedua agar anggota lebih aktif dalam kegiatan pembelajaran dan dalam upaya mengasah mental dan terbiasa berbicara di depan umum, Metode diskusi tidak sama dengan berdebat, diskusi selalu diarahkan pada problem solving yang memadukan beberapa pendapat namun pada akhirnya diambil suatu kesimpulan yang dapat diterima oleh semua kelompok. Jadi, semua anggota dapat menyampaikan pendapat pada sesi kedua dengan argumen yang beralasan dan masuk akal. ${ }^{25}$

Metode diskusi sangat tepat diterapkan pada kegiatan pembelajaran Kitab Kuning dengan Bahasa Inggris sesi kedua. Hasilnya sangat jelas terlihat pada anggota, pembelajaran sesi kedua berjalan dengan efektif dan suasana kelas tidak fakum dan monoton. Anggota saling menyampaikan argumen mengenai materi yang dibahas pada kegiatan yang sedang berlangsung saat itu dan terlihat merata baik anggota senior maupun junior.

\footnotetext{
${ }^{22}$ Wawancara dengan Guru Pengajar Faishal Khair 9 Oktober 2019.

${ }^{23}$ Wawancara dengan direktur EAL M. Ramdan Efendi 9 Oktober 2019.

${ }^{24}$ Mulyono, Strategi Pembelajaran, 111.

${ }^{25}$ Wawancara dengan Imron Habibi salah satu totur EAL 9 Oktober 2019.
} 


\section{Pemahaman Santri dalam Pembelajaran Kitab Kuning dengan Bahasa Inggris di Pondok Pesantren Annuqayah Latee}

Pembahaman materi yang dijelaskan oleh seoran guru bagi pelajar sendiri merupakan salah satu tujuan dari pendidikan yang ingin dicapai, karena pemahaman tersebut merupakan kondisi yang mutlak yang harus dipenuhi dalam teori kognetif. ${ }^{26}$ Seorang pelajar juga dituntut untuk bisa konsentrasi dan fokus pada materi yang disampaikan oleh seorang guru, karena keduanya harus saling mendukung dalam mensukseskan penyelenggaraan pembelajaran. Sardiaman dalam Jurnal Devi menyebutkan Pemahaman dapat diartikan menguasai sesutau dengan pikiran, oleh karena itu belajar harus paham atau mengerti secara mental makna dan filosofinya mkasud dari implikasi dan aplikasi-aplikasinya, sehingga menyebabkan pelajar dapat memahami sesuatu dengan benar. ${ }^{27}$ Tidak mudah bagi seorang pengajar untuk memberikan pemahaman terhadap pelajar yang notabene berasal dari berbagai latar belakang pendidikan, keluarga dan lingkungan. Seorang pengajar dituntut untuk lebih kreatif dalam inovatif dalam menyajikan pembelajaran agar pelajar dapat dengan mudah memahami materi yang disampaikan. Tidak hanya seorang pengajar yang dibebani tugas berat dalam upaya mensuskseskan proses pembelajaran, pelajar juga harus berpatisipasi dalam proses pembelajaran. Apalagi pelajar yang menjadi tolak ukur utama pembelajaran dapat dikatakan sukses atau tidak, terutama dalam memahami materi yang disampaikan oleh pengajar.

Strategi pembelajaran adalah suatu pola yang direncanakan dan ditetapkan untuk melakukan kegiatan atau tindakan. Strategi mencakup tujuan kegiatan, pihak yang terlibat dalam kegiatan, isi kegiatan, proses kegiatan dan sarana penunjang kegiatan. ${ }^{28}$ Seorang pengajar dalam mengajarkan harus mempunyai strategi dan teknik dalam upaya memberikan pemahaman yang cepat dan tepat. Stretegi yang tidak baik akan mempengaruhi waktu pembelajaran. Semakin baik strategi yang dipilih akan membuat efesiensi waktu yang lumayan baik.

Kegiatan tersebut merupakan salah satu kegiatan utama yang dari beberapa kegiatan yang terencana di EAL, mengingat kegiatan pembelajaran Kitab Kuning merupakan kegiatan utama pengurus dan pengajar dituntut untuk memilih metode yang tepat efesien. Kemudian berdampak terhadap pemahaman santri dalam proses pembelajaran Kitab Kuning. Santri harus memahami materi yang disampaikan baik dari segi makna dan kandungan yang terdapat dalam kitab tersebut.

Hasil wawancara dengan pengurus menunjukkan bahwa pemahaman santri terhadap pembelajaran Kitab Kuning sangat baik terbukti hal tersebut dapat dilihat pada sesi kedua, para anggota dapat mempresentasikan kitab kuning yang telah dipelajari pada sesi pertama dan fakta yang terjadi di lapangan para santri atau anggota EAL dapat memahami penjelasan dengan menggunakan Bahasa Inggris. ${ }^{29} \mathrm{Hal}$ tersebut terjadi karena setiap hari anggota dan pengurus menggunakan Bahasa Inggris sebagai alat komunikasi hanya saja bagi anggota baru atau junior masih butuh pembiasaan karena masih tergolong anggota baru dan butuh lebih banyak kosakata, serta pada sesi kedua yaitu sesi diskusi sangat memberikan banyak ilmu dan tambahan kosakata baru kepada semua anggota karena anggota mendiskusikan sendiri teks dan isi kandungan

\footnotetext{
${ }^{26}$ M. Ngalim Purwanto, Evaluasi Hasil Belajar, (Jogjakarta: Pustaka Pelajar, 2011), 42.

${ }^{27}$ Dewi Afriyuni Yonanda, "Peningkatan pemahaman siswa Mata Pelajaran PKn Mambaul Ulum Tegalgondo Karang Ploso Malang" Jurnal Cakrawala Pendas Vol. 3 No 1 (Januari 2017), 56.

${ }^{28}$ Abdul Majid, Strategi Pembelajaran, (Bandung: PT. Remaja Rosdakaraya, 2014), 4.

${ }^{29}$ Wawancara dengan Imron Habibi 9 Oktober 2019.
} 
Kitab Kuning yang telah dipelajari pada sesi pertama. Dari hasil penelitian yang telah dilaksanakan menunjukkan bahwa pemahaman anggota terhadap pembelajaran Kitab Kuning dengan Bahasa Inggris sangat baik.

\section{Kendala-Kendala Pembelajaran Kitab Kuning dengan Bahasa Inggris di Pondok Pesantren Annuqayah Latee}

Pelaksanaan sebuah kegiatan tentu tidak selalu berjalan dengan lancar, terdapat beberapa kendala yang dihadapi dalam menjalankan kegiatan tersebut dan kendala-kendala tersebut seringkali menjadi tantangan tersendiri dalam menjalankan sebuah kegiatan tarutama dalam kegiatan pembelajaran. Kendala merupakan suatu kondisi yang dapat menjadi penghalang tercapainya suatu kegiatan. ${ }^{30}$ Setiap lembaga atau organisasi dalam menjalankan kegiatan pasti menemukan kendala yang berbeda-beda, hal tersebut dapat terjadi karena rencana dan target dari kegiatan yang tidak sama, tergantung dari lembaga atau organisasi tersebut.

Begitu juga seorang guru dituntut untuk lebih kreatif dalam melaksanakan kegiatan pembelajaran agar pelajar tidak merasa jenuh atau mengantuk. Dalam mengelola kelas, seorang pengajar hendaknya melakukan beberapa hal agar kegiatan pembelajaran berjalan kondusif salah satunya pengaturan tempat duduk pelajar. Pengaturan kelas hendaknya dilakukan setiap minggu agar pelajar tidak mengalami kejenuhan dalam proses belajar. ${ }^{31}$ Pendapat lain mengemukakan seorang guru perlu mengalami latihan-latihan secara kontinu dan sistematis, sebagai fasilitator guru hendaknya mengusahakan sumber belajar yang berguna serta menunjang pencapaian tujuan dan proses belajar mengajar. ${ }^{32}$

Lembaga Bahasa Inggris Pondok Pesantren Annuqayah Latee juga mengalami beberapa kendala dalam menjalankan kegiatan. Apalagi kompleksitas kegiatan yang dijalankan cukup tinggi yaitu kegiatan pembelajaran Kitab Kuning dengan Bahasa Inggris. Belajar Kitab Kuning saja sangat sulit dan membutuhkan waktu yang lama apalagi ditambah dengan menggunakan Bahasa Inggris. Beberapa kendala yang dihadapi oleh lembaga tersebut yakni sebagai berikut:

Kendala pertama dalam kegiatan ini yaitu mengenai waktu pelaksanaan sesi pertama, pelaksanaan sesi pertama dilaksanakan pada waktu pagi. Jadi, terdapat beberapa anggota yang mengantuk dan bahkan ada yang sampai tertidur. Masalah tersebut diatasi dengan memindahkan tempat duduk untuk santri yang mengantuk dan pengurus juga bertindak utuk menegur anggota yang mulai mengantuk atau bahkan tertidur.

Kendala kedua yaitu tingkat pemahaman anggota yang berbeda, hal tersebut karena terdapat sebagian angggota yang berstatus anggota baru atau anggota junior. Jadi belum terbiasa dengan kegiatan tersebut dalam arti belum terbiasa dalam kegiatan pembelajaran Kitab Kuning dengan Bahasa Inggris. Namun, kendala itu dapat diatasi pada sesi diskusi sebelum masuk pada sesi kedua. Anggota bersama kelompok masing-masing saling berbagi informasi mengenai materi yang belum dipahami oleh anggota yang lain.

Kendala ketiga yang dihadapi datang dari pengurus sendiri, hal ini terdapat beberapa pengurus yang tidak berperan serta dalam kegiatan sesi

\footnotetext{
${ }^{30}$ Soewarno dkk. "Kendala-Kendala yang Dihadapi Guru Dalam Memanfaatkan Media Komputer di SD Negeri 10 Banda Aceh", Jurnal Pesona Dasar, Vol. 2 No. 4 (April 2016.) 30.

${ }^{31}$ Tukirno, "Kesulitan-Kesulitan dalam Pelaksanaan Pembelajaran Seni Budaya dan Keterampilan kelas V SDN Arjosari 01 Blimbing". (Juli 2012). 9.

${ }^{32}$ Jasmani Asf. Supervisi Pendidikan, (Jogjakarta: Ar- Ruzz Media 2013), 177.
} 
pertama, kendala ini berpengaruh pada pelaksanaan kegiatan sesi kedua. Jika pengurus tidak mengikuti kegiatan pembelajaran sesi pertama maka otomatis akan kesulitan ketika akan melaksanakan kegiatan pembelajaran sesi kedua dan apabila terdapat anggota yang bertanya akan sulit menjelaskan materi yang disampaikan pada sesi pertama, kendala ini cukup sulit diatasi karena selain Direktur melakukan teguran kepada pengurus yang absen pada kegiatan sesi pertama juga perlu ditumbuhkan kesadaran kepada pengurus yang bersangkutan.

\section{Kesimpulan}

Pembelajaran Kitab Kuning dengan Bahasa Ingris di Pondok Pesantren Annuqayah Latee dilaksanakan dua kali dalam satu minggu yaitu sesi pertama dilaksanakan setelah sholat subuh sekitar jam 05.00 WIB sampai jam 06.00 WIB sedangkan sesi kedua, dilaksanakan sekitar jam 20.30 WIB sampai jam 22.00 WIB dan terdapat dua metode yang digunakan yaitu metode bandongan dan metode diskusi. Metode bandongan dipilih dalam upaya anggota dapat mengetahui makna dari teks dan memahami penjelasan yang terkandung dalam Kitab Kuning dengan baik dan benar. Metode diskusi, metode ini bertujuan agar anggota dapat mendiskusikan Kitab Kuning yang telah dipelajari pada sesi pertama dan menuntut anggota lebih aktif dalam kegiatan pembelajaran.

Pemahaman santri dalam memahami pembelajaran Kitab Kuning dengan Bahasa Inggris dapat dikatakan sangat baik, hal tersebut terbukti pada sesi kedua, para anggita dapat mempresentasikan hasil belajar pada sesi pertama dan dapat saling bertukar pendapat serta didukung dengan penggunaan Bahasa Inggris sebagai Bahasa komunikasi setiap hari serta sesi kedua sangat memberikan banyak ilmu dan tambahan kosakata baru kepada anggota dalam mendiskusikan teks dan isi kandungan Kitab Kuning.

Kendala-kendala yang dihadapi dalam kegiatan tersebut yaitu, pelaksanaan sesi pertama setelah shalat subuh membuat anggota mudah mengantuk bahkan terdapat beberapa anggota yang tidur, pemahaman anggota yang berbeda-beda karena status keanggotaan, anggota senoir lebih mudah memahami materi karena sudah terbiasa sedangkan anggota junior masih butuh beradaptasi, kendala terakhir terdapat pengurus yang tidak mengikuti kegiatan sesi pertama sehingga akan kurang menguasai melaksanakan kegiatan sesi kedua dan sulit membantu anggota yang kurang paham terhadap materi.

\section{Daftar Pustaka}

Afriyuni Yonanda, Dewi, 201, "Peningkatan pemahaman siswa Mata Pelajaran PKn Mambaul Ulum Tegalgondo Karang Ploso Malang" Jurnal Cakrawala Pendas Vol. 3 No .

Creswell, Jhon W., 2012, Research, Pendekatan Kualitatif dan kuantitatif dan Mixed. Terjemah oleh, Ahmad Fawaid, Jakarta: Pustaka Pelajar.

E Stake, Robert, Study Kasus dalam Densin, Norman K. dan Linclon Younna, (Handbooks of Qualitative research). Terjemah oleh, Dariynato, Badrus Samsul Fata dan Jhon Rinadi, Jogjakarta: Pustaka Pelajar.

Fadli, Adi, 2012, "Pesantren: Sejarah dan Perkembangannya", EL- HIKAM: Jurnal Pendidikan dan Kajian Kelslaman, Vol. V Nomor 1.

Hadi Sutrisno, Budiono, 2009, Sejarah Wali Songo Misi Pengislaman di Tanah Jawa, Jogjakarta Graha Pustaka.

Hamzah, Amir, 2009, Metode Penelitian Kualitatif, Rekonstruksi Pemikiran Dasar, Malang: Literasi Nusantara. 
Jamaluddin, Muhammad, 2012, "Metamorfosis Pesantren di Era Globalisasai", Jurnal KARSA, Vol 20 no 1

Jasmani Asf, 2013, Supervisi Pendidikan, Jogjakarta: Ar- Ruzz Media.

Majid, Abdul, 2014, Strategi Pembelajaran, Bandung: PT. Remaja Rosdakaraya.

Muhakamurrohman, Ahmad, 2014, "Pesantren, Santri, Kiai dan Tradisi", Jurnal Kebudayaan Islam, Vol. 12, No. 2.

Priyatna, Muhammad, 2017, "Manajemen Pembelajaran Program Kulliyatul Mu'allimin al-Islamiyah di Pondok Pesantren al-Ihsan Baledah Bandung", Jurnal Edukasi Islami Pendidikan Islam, Vol. 6.

Purwanto, M. Ngalim, 2011, Evaluasi Hasil Belajar, Jogjakarta: Pustaka Pelajar.

Soewarno dkk. 2016, "Kendala-Kendala yang Dihadapi Guru Dalam Memanfaatkan Media Komputer di SD Negeri 10 Banda Aceh", Jurnal Pesona Dasar, Vol. 2 No. 4.

Tim Penyusun, 2018, Laporan Akhir Tahun English Area of Latee Pondok Pesantren Annuqayah Latee.

Tim Penyusun, 2018, Laporan Akhir Tahun Pondok Pesantren Annuqayah Latee, Sumenep: Alatee Press.

Tim Penyusun, Jejak Masyayikh Annuqayah, Kado Alumni Pondok Pesantren Annuqayah Latee, Sumenep: Alatee Press.

Tukirno, 2012, "Kesulitan-Kesulitan dalam Pelaksanaan Pembelajaran Seni Budaya dan Keterampilan kelas V SDN Arjosari 01 Blimbing".

Wahid, Abdurrahman, 2001, Menggerakkan Trasidi: Esai-Esai Pesantren. Jogjakarta: LkiS.

Wawancara dengan direktur EAL M. Ramdan Efendi 9 Oktober 2019.

Wawancara dengan Guru Pengajar Faishal Khair 9 Oktober 2019.

Wawancara dengan tutor EAL Imromn Habibi 9 Oktober 2019. 